\title{
Confirmation of adherence Protein Hemagglutinin sub-unit Pili with MW 49.6 kDa Helicobacter pylori on Mice Gastric Epithelial Cell
}

\author{
Hamong Suharsono ${ }^{1}$, Made Agus Hendrayana ${ }^{2}$, I Nyoman Mantik ${ }^{3}$ and \\ Sumarno Reto Prawiro ${ }^{2}$ \\ ${ }^{1}$ Laboratory of Biochemistry Veterinary Faculty University of Udayana Denpasar, Indonesia \\ ${ }^{2}$ Laboratory of Microbiology Medical Faculty University of Udayana Denpasar, Indonesia \\ ${ }^{3}$ Laboratory of Virology Veterinary Faculty University of Udayana Denpasar, Bali Indonesia \\ ${ }^{4}$ Laboratory of Microbiology, Medical Faculty University of Brawijaya Malang Indonesia
}

\begin{abstract}
Helicobacter pylori (H.pylori) is a gram-negative microaerophilic bacterium that is generally associated with the main cause of approximately $80 \%$ peptic ulcers in stomach. It is also linked to the development of the stomach cancer. The aim of this study was to characterize the sub-unit pili proteins of Helicobacter pylori with a molecular weight of about 49,6 kDa as a haemagglutinin protein and adhesion molecules on surface of mice gastric epithelial cells. The bacterium was firstly cultured on the plate of TSA-B (Trypticase Soy Agar with 5\% Sheep Blood) to prepare the protein of interes using bacterial cutter. The isolated proteins were subsequently analyzed for haemagglutination capability using mice sentisized erithrocytes. SDSPAGE and western blotting analyses were used to confirm the protein patterns and their immunological reactivities respectively. The both SDS-PAGE and western blotting analyses showed that a dominant protein with molecular weight of about 49,6 kDa was detected consistently and found to be potentially aglutinate the erythrocytes. Furthermore, this protein was observed to be adherence on mice gastric epithelial cells. This study has indicated that the sub-unit pili proteins of $\mathrm{H}$. pylori with a molecular weight of about 49,6 $\mathrm{kDa}$ was found to be dominant and immunogenic. Further study is required to confirm the in vivo properties of the protein associated with pathogenesis of $H$. pylori infection.
\end{abstract}

Keywords: pili 49,6 kDa H. pylori, adhesion, gastric epithelial cell

\section{Introduction}

In the early 1980s it was known that the presence of microbes in the stomach was associated with gastric cancer. The ability of bacteria to cause cancer at the same time undermine the perception of the bactericidal power of stomach acid. The previous studies and surveys about this phenomena considered that infection of H. pylori may be one of the cause's gastric cancer (Nunes, 1998). Infection by the H.r pylori has been identified as a major cause of peptic ulcer disorder (gastric and duodenal ulcers), gastritis chronic and gastric carcinoma even gastric lymphoma. This is unique, because Helicobacter pylori is the only one bacterium known to cause gastric carcinoma (Clyne, et al., 2007). Infectious $H$. pylori was classified as carcinogens group I for gastrointestinal cancer (WHO, 1994), because it has various virulent factors such as CagA, VacA, Urease, and ammonia that capable to trigger carcinogenesis. The pathogenic properties of this bacteria was associated with its fimbrial adhesion (pili), a protein found on the bacterial cell surface that play a role as a bacterial virulence factor (Salyer \& Whitt, 2002). In some bacteria, adhesion has antigenic reactivity to agglutinate erythrocytes, called haemagglutinin protein (Nagayama et al., 1995).

Until now there has been limited studies regarding the pathophysiological effects of $H$. pylori in the gastrointestinal tract. The diagnosis of peptic ulcers has been based on gastric biopsy, urea breath test, and serological tests for the existence of antigen CagA and VacA (Cover and Blanke, 2005). Diagnosis based on serological test such ELISA and FAT could not be applied to detect antibodies during acute infections, because antibody response against CagA and VacA will appear late after infection (Groves, et al., 2001; Leite, et al., 2005). Therefore it is necessary to find other techniques for the diagnosis of $H$. pylori infection. However, the in vitro study to demonstrate the biological mechanism of the protein in causing this condition is very limited. Primary cell culture and gastric epithelial cells of the stomach of mice will be used in this research to study the molecular character of adhesion H. pylori isolates Mataram Lombok Indonesia. This research will open a new era of advanced research to get a diagnosis tools and vaccine of peptic ulcer disease that caused by H. pylori based on molecular adhesion. The purpose of this research is to prove that haemagglutinin molecule pili 49,6 $\mathrm{kDa}$ is a gastric epithelial cell adhesion. 


\section{Materials And Methods \\ Helicobacter pylori isolate and cultivation}

Helicobacte pylori strain was isolated from patient with gastritis and duodenum ulcer, kindly provided by Biomedical Research Unit Lombok West Nusa Tenggara Provincial Hospital Indonesia. The bacterium was firstly cultured using media Trypticase Soy Agar (TSA) and Trypticase Soy Broth (TSB) supplemented with $10 \%$ sheep blood, Dent supplement and Isovitalex and incubated at $37 \mathrm{C}$ on microaerophilic atmosphere.

\section{SDS-PAGE analysis}

To determine molecular weight (MW) of protein, SDS-PAGE analysis was done according to Laemmli methods (1970). A total of $0.5 \mathrm{ml}$ samples of pili with a concentration of about $100 \mu \mathrm{g}$ was firstly mixed with similar amount of reducing buffer containing $5 \mathrm{mM}$ Tris HCL pH 6,8,5\% 2-mercapto ethanol, 2,5\% w/v sodium dodecyl sulfate, $10 \% \mathrm{v} / \mathrm{v}$ glycerol that containing color tracker blue bromophenol and boiled at $100^{\circ} \mathrm{C}$ for 5 minutes. The denatured proteins was subjected into 12,5\% mini slab gel with tracking gel $4 \%$ together with a low range protein marker (Sigma), electrophoresed with $125 \mathrm{mV}$ for 45 minutes. The gel was then stained with Coomassie briliant blue and de-stained with $60 \%$ ethanol until all protein bands were observed, and photograped.

\section{Hemaglutination assay}

Hemaglutination assay was performed according to Hanne and Finkelstein (1982). Sample to be tested is whole cell lysate, protein pili, and Outer membrane protein. Serial dilution of samples was prepared as double serial dilutions from at 1:2, to 1: 64 from original concentration on $\mathrm{V}$ micro plate. To test agglutinin of protein sub unit pili, $50 \mathrm{uL}$ of each dilution of pili fraction was drooped into well of plate A (pili fraction 1, from row A 2 A 6; pili fraction 2 from row A3 to A6 and pili fraction 3, from row A4 to A6 respectively. As negative control $50 \mathrm{uL}$ of PBS pH 7.2 was drooped into each well, row A1 to A6 and from row A5 to A6 (Fig. 2A). Similar reaction was also done for OMP proteins in Plate B. Subsequently, a drop of $50 \mathrm{uL}$ of mice sensitized red blood cell with concentration of $0,5 \%$ was added into each well, shaken with plate rotator for 1 minute and incubated at room temperature for one hour. The titer was determined by observing the agglutination of red blood cells.

\section{Isolation protein haemaglutinin sub unit pili 49,6 kDa H.pylori}

Haemagglutinin protein of $49,6 \mathrm{kDa}$ sub-unit pili was isolated from gel by cutting a long side close to the protein positions, around 49,6 $\mathrm{kDa}$. The isolated gel was sliced and inserted into the dialisa membrane soaked with PBS buffer. Subsequently, protein of interes was electro eluted by placing the membrane in the negative electrode with current $20 \mathrm{~mA}$ for 15 minutes. Total protein was measured using a method derived DC Protein Assay (Biorad), suspended to a concentration of about $10 \mathrm{ng}$ per $\mathrm{ml}$ and kept at $-20^{\circ} \mathrm{C}$ until used.

\section{The production of rabbit polyclonal antibodies to prepare IgG against the sub unit pili 49,6 kDa protein}

Polyclonal antibodies was prepared in a New Zealand healthy rabbit by immunizing it with immunogen, three times one week interval. At the first, the animal was immunized intramuscularly with $1 \mathrm{ml}$ of emulsified immunogen contained $20 \mathrm{ng}$ in Freunds complete adjuvant. The second and third immunization were given with the same dose of antigen but with Freunds incomplete adjuvant. One week after the last vaccination, blood was taken for serum. To purify IgG, serum was precipitated using ammonium sulfate, aliquoted $100 \mu \mathrm{L}$ each and stored at $-20{ }^{\circ} \mathrm{C}$ until used.

\section{Western blotting analysis}

Western blotting analysis was performed according to Towbin (1979). Protein of interes was subjected into SDS-PAGE gel and transfered to PVDF membran using mini Transblot Cell (Biorad, USA). The cell was soaked with Tris Borate buffer $\mathrm{pH} 8.3$, run at $100 \mathrm{~V}$ contants voltage for one hour. Subsequently, membrancontained tranfered proteins was blocked with 5\% nonfat skim milk for 30 minutes at room temperature, to block non-spesific binding site. The first antibody (IgG) with 1:100 dilution with PBS was then added into the membrane, incubated for $1 \mathrm{~h}$ at room temperature. After washing with TBE Tween20 twice, the membran was incubated with goat-anti rabbit HRP-conjugated antibody solution, as recomended by the manufacture. Finally, the membrane was again washed before colour development beeing done, washed with $\mathrm{H} 2 \mathrm{O}$, dried and photograph.

\section{Mice gastric epithelial cell preparation}

The gastric epithelial cell of mice was prepared according to Weiser methods (Nagayama et al, 1995) with slight modification. Briefly, mice gastric was opened aseptically, with transverse cutting method, its contents was removed and washed 3 times using PBS pH 7,4 containing $1 \mathrm{mM}$ dithiothreithol at $4^{\circ} \mathrm{C}$. The gastric 
was then soaked with a solution $(\mathrm{pH} \mathrm{7.3)} \mathrm{containing} 1,5 \mathrm{mM} \mathrm{KCl}, 9,6 \mathrm{mM} \mathrm{NaCl}, 2,7 \mathrm{mM}$ Na-citrate, $8 \mathrm{mM}$ $\mathrm{KH}_{2} \mathrm{PO}_{4}$ and 5,6 mM cold $\mathrm{Na}_{2} \mathrm{HPO}_{4}$, before being incubated at $37^{\circ} \mathrm{C}$ for 30 minutes with gentle shaking. The supernatant was removed, and the tissue was transferred into PBS containing $1.5 \mathrm{mM}$ EDTA and 0,5 dithiothreithol and incubated for a further $15 \mathrm{~min}$ at $37^{\circ} \mathrm{C}$ with vigorous shaking. Again, the supernatant was removed, and the cells were washed with PBS by three centrifugation at $900 \mathrm{xg}$ for $5 \mathrm{~min}$ at $4^{\circ} \mathrm{C}$. Isolated gastric cells were harvested by a further centrifugation at $900 \mathrm{xg}$ for $5 \mathrm{~min}$ at $4^{\circ} \mathrm{C}$ and suspended in $\mathrm{PBS}$ containing $1 \%$ Bovine serum albumin (BSA), counted with a hemcytometer to a concentration of about $10^{6}$ cells per ml. The suspended cells were kept at $4^{\circ} \mathrm{C}$ until required for Immunohistochemistry and adherence assays.

\section{Immunocytochemistry method}

Immunocytochemistry was performed using reagents LSAB2 System HRP (Dako Cytomation). A total of $100 \mathrm{uL}$ cell suspension was spread over the glass slide, air-dried and fixed with absolute methanol. The slides were then treated with $3 \% \mathrm{H}_{2} \mathrm{O}_{2}$ in distilled water for 5 min to block endogenous peroxidase, then washed an additional 3 times with distilled water. Subsequently, $100 \mu \mathrm{l}$ of the 49,6 kDa subunit pili protein was dropped onto the slide and incubated for 30 minutes at room temperature. After incubation with the antigen, the slides were then washed 3 times with PBS and $100 \mu$ of the rabbit IgG as prepared above was added and incubated for 30 minutes at room temperature. The slides were again washed 3 times with PBS, and two drops of biotinylated link secondary antibody were then added to the slide and incubated for $15 \mathrm{~min}$. The slides were again washed 3 times with PBS, and then 2 drops of peroxidise-labelled streptavidin was added to the slides and incubated for 10 min. After a further 3 washes with PBS the colour reaction was developed by adding 3-3'diaminobenzidine (DAB) for 3-5 min. The slides were then washed with distilled water, dried before being examined by light microscope. Negative controls were provided by omitting either the antigen or IgG solution.

\section{Adherence inhibition assay of $\boldsymbol{H}$. pylori to mice gastric epithelial cells}

A serial dilution of $100 \mu \mathrm{L} \mathrm{IgG} \mathrm{suspension} \mathrm{from} \mathrm{1:1} \mathrm{to} \mathrm{1:8} \mathrm{was} \mathrm{made,} \mathrm{each} \mathrm{of} \mathrm{it} \mathrm{was} \mathrm{mixed} \mathrm{with} 100 \mathrm{uL}$ gastric epithelial cells $\left(10^{6}\right.$ cells $\left./ \mathrm{mL}\right)$. The mixture was then allowed to incubate at $37^{\circ} \mathrm{C}$ for 30 minutes with gentle shaking. The cells were collected by centrifugation at $900 \mathrm{xg}$ for 5 minutes. The cell pellet from each different mixture was suspended with similar amount of $100 \mathrm{uL}$ of $H$. pylori cells $\left(10^{5} \mathrm{cells} / \mathrm{mL}\right)$, and the nonadherent cells were removed by repeated washing with PBS containing 1\% BSA. Finally, 100 uL cell suspension was stained with $0,5 \%$ Tryphan Blue, and examine by phase-contrast microscopy at a magnification of 1000x. An adherence index was calculated as the mean number of gastric epithelial cells per bacteria determined in three separate experiments.

\section{SDS-PADE analysis}

\section{Results}

The SDS-PAGE analysis showed that obviously 5 major protein bands were detected with molecular weight of about $80 \mathrm{kDa}, 60 \mathrm{kDa}, 54 \mathrm{kDa}, 49,6 \mathrm{kDa}$ and $47 \mathrm{kDa}$ respectively (Fig 1). A protein band of interest with the molecular weight of $49,6 \mathrm{kDa}$ was consistently observed. This protein band was sliced and electroeluted for further analysis.

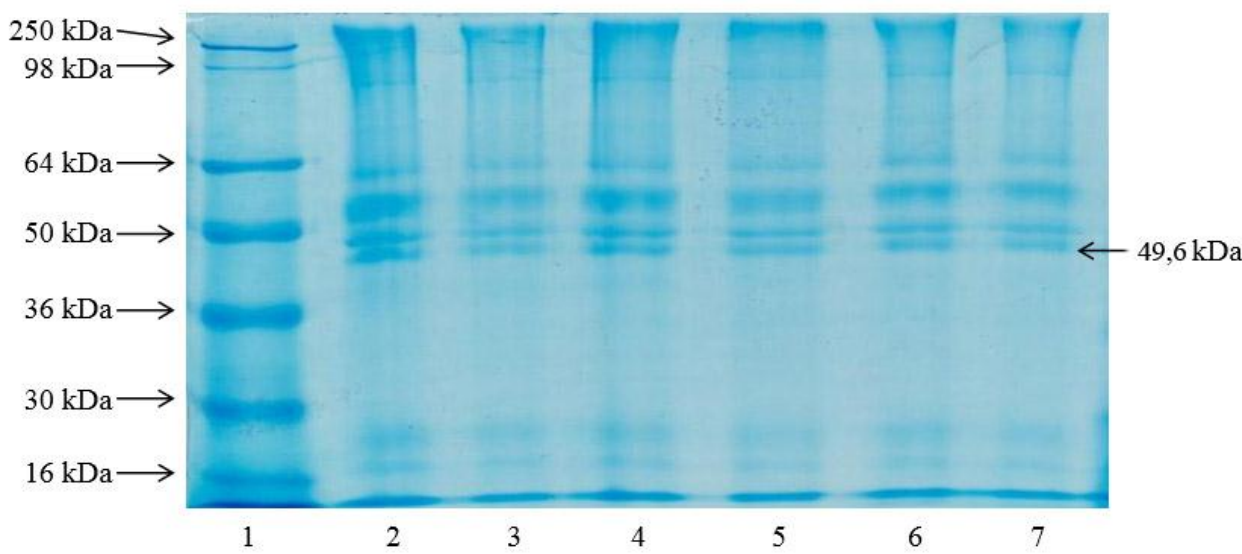

Figure 1. SDS-PAGE analysis of $H$. pylori pili protein. Lanes 1: A low range molecular weight marker, 27: protein profile of H.pylori pili that consisted of five major protein bands namely with molecular weight of about $80 \mathrm{kDa}, 60 \mathrm{kDa}, 54 \mathrm{kDa}, 49,6 \mathrm{kDa}$ and $47 \mathrm{kDa}$ respectively. 


\section{Haemagglutination assay}

Both the pili and outer membrane originated proteins of $H$. pylori were examined for haemagglutination of mouse erythrocytes. Of the 3 pili protein fractions isolated, fraction 3 showed the highest haemagglutination titer of $1 / 16$ (Fig.2 A). Fraction 2 had a low titer of $1 / 4$ but fraction 1 had no haemagglutination reactivity, similar to negative, PBS control. Meanwhile, among the OMP fraction proteins, only fraction 2 showed strong haemagglutination titer of 1/8 (Fig. 2B), but all of negative control (PBS) had no haemagglutination properties.
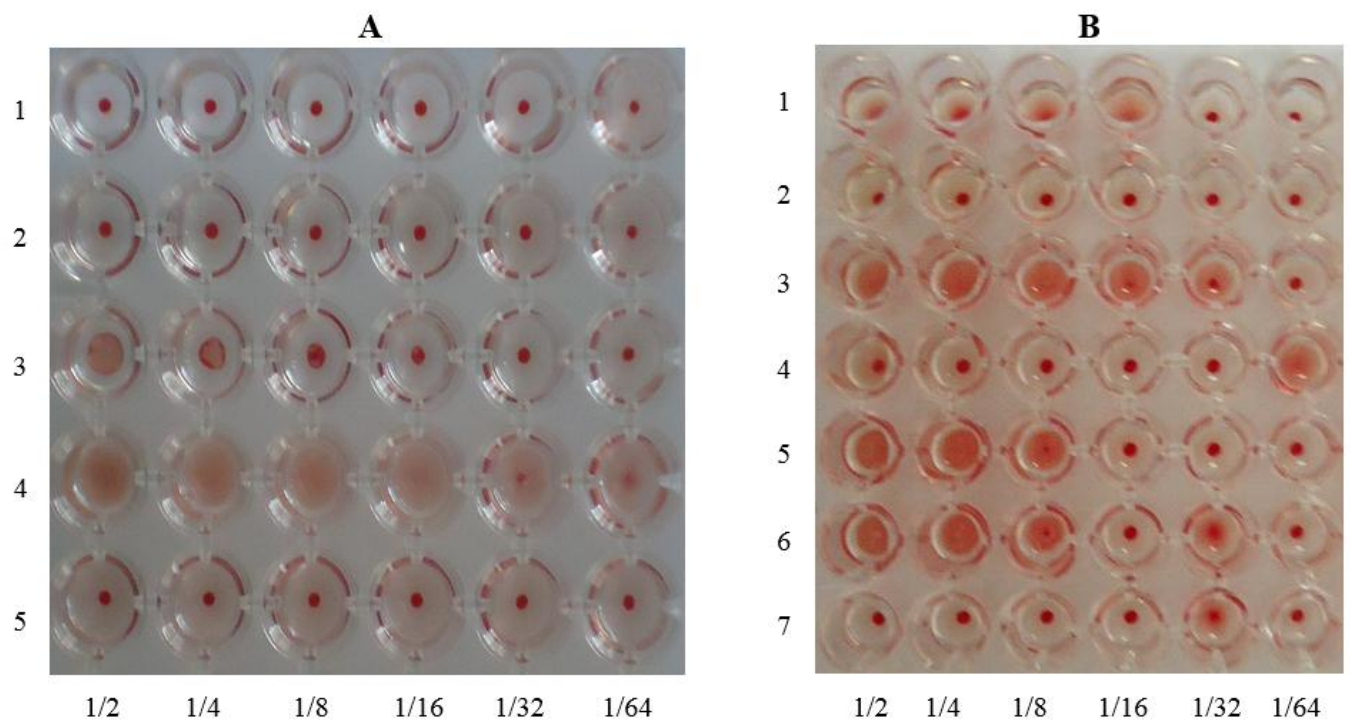

Figure 2A. Haemagglutination test of $H$. pylori protein sub unit pili in serial shearing process

Figure 2B. Haemagglutination test of $H$. pylori protein sub unit pili and OMP H. pylori using mice

\section{Legend : A.1: blanko/PBS \\ A.2: pili fraction 1 \\ A.3: pili fraction 2 \\ A.4: pili fraction 3 \\ A.5: blanko/PBS}

B.7: blanko/PBS

B.6: OMP fraction 3

B.2: pili fraction 2

B.5: OMP fraction 2

B.4: OMP fraction 1

B.3: pili fraction 3

B.1: pili fraction 1

\section{Western blotting analysis}

Hyper immunized rabbit against sub unit pili 49,6 kDa proteins was tested by Western blotting to confirm the presence of the expected antibodies. A protein band with molecular weight of about $49.6 \mathrm{kDa}$ showed the strongest reactivity suggesting that this protein was immunogenic and immunodominant, although other minor protein bands were also observed (Fig. 3).

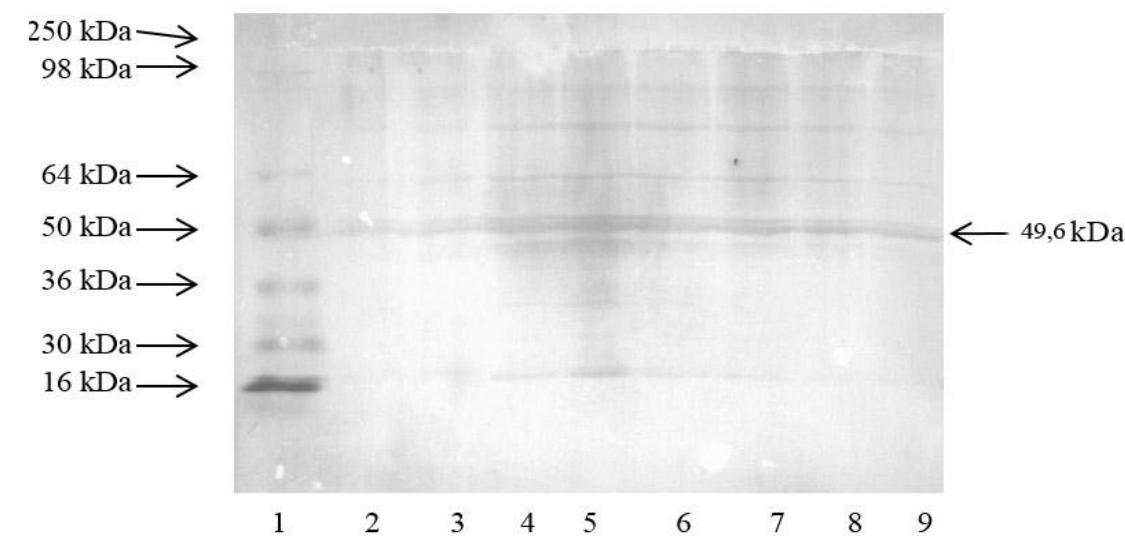

Figure 3. Western blot analysis of protein sub unit pili from sequential cutting $H$. pylori against rabbit polyclonal anti-H. pylori showed that the polyclonal antibodies reacted strongly with protein sub unit pili with MW of about 49,6 kDa, compared to other protein components . Lanes: 1. Molecular weight Marker, 2-9: Protein Fractions. 


\section{Adherence inhibition assay of $\boldsymbol{H}$. pylori to mice gastric epithelial cells}

To confirm directly that $H$. pylori has the ability to adhere to mice gastric epithelial cells, the inhibitory effects of the isolated sub unit pili $49,6 \mathrm{kDa}$ proteins and the $\mathrm{IgG}$ prepared from a polyclonal antiserum produced against the purified sub unit pili $49,6 \mathrm{kDa}$ proteins were examined by incorporating these preparations into the assay model at different concentrations. The pre-treatment of the mice gastric epithelial cells with the purified sub unit pili $49,6 \mathrm{kDa}$ proteins to protect the receptor involved in the adherence repealed in an inhibition of further of the $H$. pylori cells to mice gastric epithelial cells in dose-dependent manner with respect to the amount of IgG dilution added (Fig. 4 A, B, C). This result indicated that the higher levels of antibodies coated to gastric epithelial cells, the less bacteria attached to the gastric epithelial cells. However, non-immune IgG fraction had no effect on the adherence

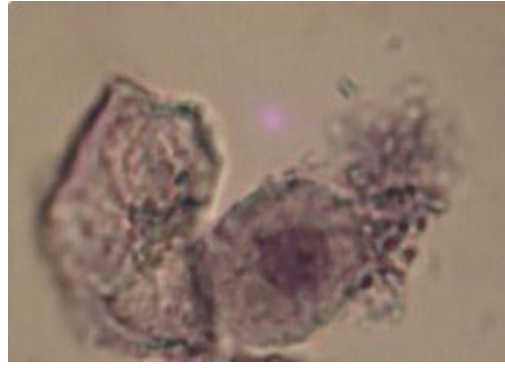

A

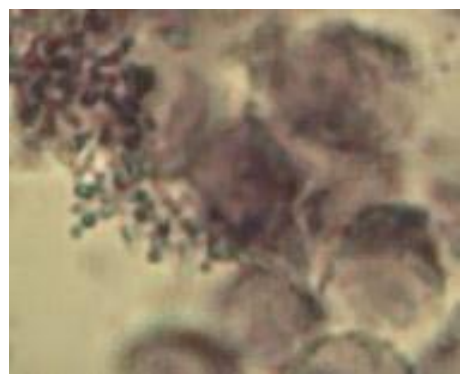

B

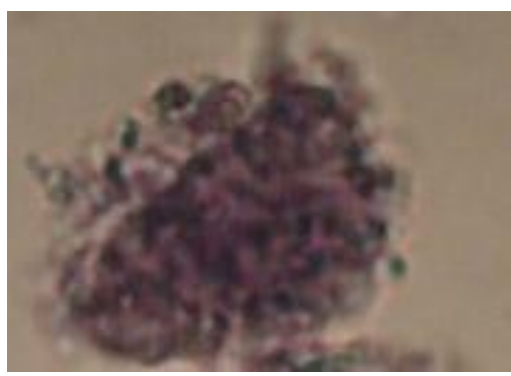

C

Figure 4. Gastric epithelial cells that had been coated with antibodies and then attached by H. pylori, showed a little adherence of the bacteria on the cells, compared to the non-coated antibody-cells.

Table 1. Calculation results of gastric epithelial cells of mice with antibody and H. pylori (positive) for every 100 field of views.

\begin{tabular}{|c|c|c|c|c|}
\hline Treatments & Repeated & $\begin{array}{c}\text { Showed Positive } \\
\text { Results }\end{array}$ & $\operatorname{Mean}(\bar{x})$ & $\begin{array}{c}\text { Adhesion } \\
\text { Index }\end{array}$ \\
\hline $\mathrm{T}_{1}$ & $\mathrm{R}_{1}$ & 20 & & \\
\hline (Gastric epithelial cells $+1 / 2$ dilution antibody & $\mathrm{R}_{2}$ & 10 & 19,33 & 0,19 \\
\hline$+10^{4} \mathrm{H}$. pylori $)$ & $\mathrm{R}_{3}$ & 28 & & \\
\hline $\mathrm{T}_{2}$ & $\mathrm{R}_{1}$ & 27 & & \\
\hline (Gastric epithelial cells $+1 / 4$ dilution antibody & $\mathrm{R}_{2}$ & 20 & 25,00 & 0,25 \\
\hline$+10^{4} \mathrm{H}$. pylori $)$ & $\mathrm{R}_{3}$ & 28 & & \\
\hline $\mathrm{T}_{3}$ & $\mathrm{R}_{1}$ & 49 & & \\
\hline (Gastric epithelial cells $+1 / 8$ dilution antibody & $\mathrm{R}_{2}$ & 55 & 44,67 & 0,45 \\
\hline$+10^{4} \mathrm{H}$. pylori $)$ & $\mathrm{R}_{3}$ & 30 & & \\
\hline
\end{tabular}

From Table 1 it shows that the higher levels of antibodies that coated to gastric epithelial cells, the less bacteria attached to the gastric epithelial cells. This indicated that the $\operatorname{IgG}$ prepared against sub unit pili 49,6 $\mathrm{kDa}$ proteins was a homolog antibody against bacterium Helicobacter pylori.

Linear regression statistical test is then performed on the results of this study. Obtained results $\mathrm{R}^{2} 0,529$ with p 0,026 as shown in Chart 1 below.

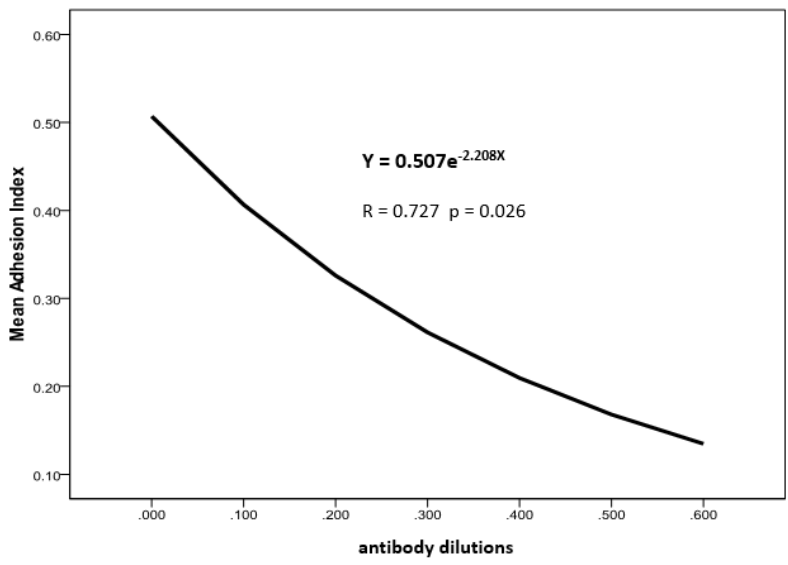

Figure 5. Model $\mathrm{Y}=\mathrm{a} \mathrm{e}^{\mathrm{bX}}$. Adhesion index (Y) coefficient (a) antibody dilution (X) attachment rate (b) 
The statistical test results indicate that there was a positive correlation between concentration antibodies and the number of bacteria attached to the gastric epithelial cells.

\section{Immunocytochemistry assay}

The haemagglutinin role of sub unit pili 49,6 $\mathrm{kDa}$ proteins as adhesion protein, was demonstrated using it Immunocytochemistry assay. The sub unit pili $49,6 \mathrm{kDa}$ proteins reacted specifically with mice gastric epithelial cells depending on the amount of protein added, the higher the concentration of protein the stronger the reaction (Fig. 6). This result confirmed that the mice gastric epithelial cells had a specific receptor to the protein or the sub unit pili $49,6 \mathrm{kDa}$ proteins had a specific adhesion molecules to bind the target gastric cells of mice.

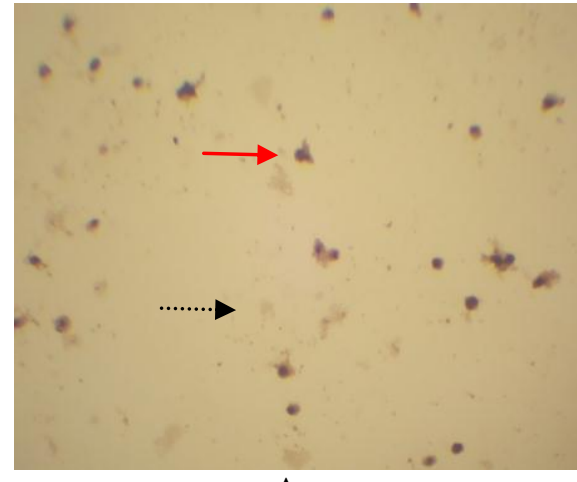

A

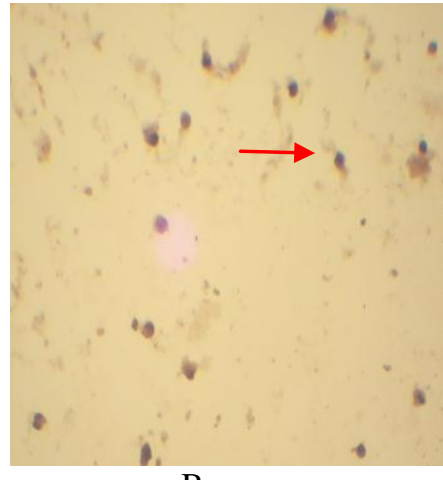

B

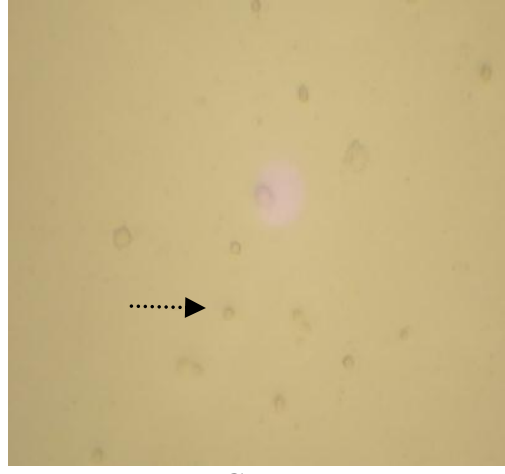

C

Figure 6. The results of immunocytochemical staining of gastric epithelial cell suspensions of mice were mixed with pili proteins. The positive reactions are indicated by dark brown dots. (A). Gastric

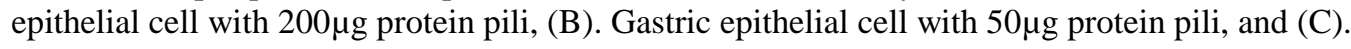

Gastric epithelial cell with $12,5 \mu \mathrm{g}$ protein pili.

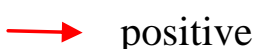

$\cdots$ negative

Adhesion index of protein pili of H. pylori in gastric epithelial cells of mice are shown in Table 2.

Table 2. Calculation results of gastric epithelial cells of mice and protein pili of $H$. pylori (positive) for every 100 field of views.

\begin{tabular}{|c|c|c|c|c|}
\hline Treatments & Repeated & $\begin{array}{c}\text { Showed Positive } \\
\text { Results }\end{array}$ & $\operatorname{Mean}(\bar{x})$ & $\begin{array}{l}\text { Adhesion } \\
\text { Index }\end{array}$ \\
\hline $\begin{array}{l}\mathrm{T}_{1} \\
(\text { Gastric epithelial cells }+200 \mu \mathrm{g} \\
\text { protein pili) }\end{array}$ & $\begin{array}{l}\mathrm{R}_{1} \\
\mathrm{R}_{2} \\
\mathrm{R}_{3}\end{array}$ & $\begin{array}{l}56 \\
60 \\
52 \\
\end{array}$ & 56 & 0,56 \\
\hline $\begin{array}{l}\mathrm{T}_{2} \\
(\text { Gastric epithelial cells }+50 \mu \mathrm{g} \\
\text { protein pili) }\end{array}$ & $\begin{array}{l}\mathrm{R}_{1} \\
\mathrm{R}_{2} \\
\mathrm{R}_{3}\end{array}$ & $\begin{array}{l}33 \\
38 \\
31 \\
\end{array}$ & 34 & 0,34 \\
\hline $\begin{array}{l}\mathrm{T}_{3} \\
(\text { Gastric epithelial cells }+12,5 \mu \mathrm{g} \\
\text { protein pili) }\end{array}$ & $\begin{array}{l}\mathrm{R}_{1} \\
\mathrm{R}_{2} \\
\mathrm{R}_{3}\end{array}$ & $\begin{array}{l}19 \\
15 \\
20\end{array}$ & 18 & 0,18 \\
\hline
\end{tabular}

Adhesion index calculations in Table 2 show the tendency of the higher concentration of the pili proteins given, the more pili that that attach to gastric epithelial cells. In Figure 6 gastric epithelial cell that attached by pili proteins showed a darker color.

Linear regression statistical test is then performed on the results of this study. Obtained results $R^{2} 0,957$ with $\mathrm{p}<0,01$ showed in Figure 7. 


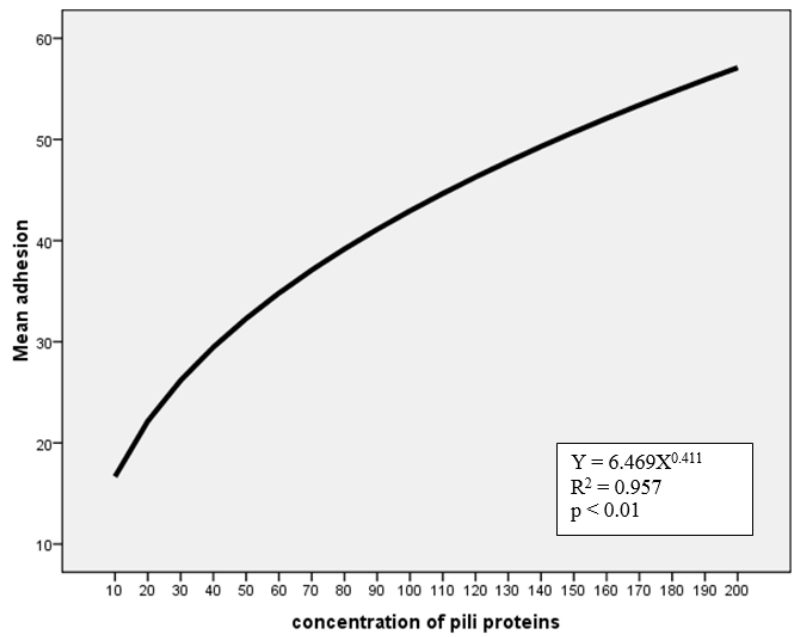

Figure 5. Model $\mathrm{Y}=\mathrm{a} \mathrm{X}^{\mathrm{b}}$. Adhesion index $(\mathrm{Y})$ coefficient (a) Concentration of pili protein $(\mathrm{X})$ attachment rate (b)

This results shows the significance that the number of pili proteins that attach to gastric epithelial cells is influenced by the number of pili concentration given.

\section{Discussion}

Kaiser (2011) stated that one of the roles of pili of certain bacteria is to allow bacteria to colonize the surface of target cells and are resistant to environmental conditions outside of the attachment. It is known that the initial step of colonization process by H. pylori is their ability to adhere the mucosal surface of gastric epithelial cells. However, information regarding the pili components particularly haemagglutinin and adhesion molecules of the bacteria is limited. In other bacteria, it was reported that a sub unit pili protein of Shigella dysentriae and Salmonella typhi with molecular weight of $49,8 \mathrm{kDA}$ and $48 \mathrm{kDa}$ respectively were hemaglutinin with adhesion properties (Wiwik et al.,, 2012, Sumarno et al., 2012).

In this study, the pathogenic properties associated with a sub unit pili $49,6 \mathrm{kDa}$ protein of $H$. pylori were investigated. In Western blot analysis, IgG purified from polyclonal antibodies prepared against the protein specifically recognized the similar antigen, indicating that the protein was immunogenic in nature. Confirmation of this protein using haemagglutination assay, showed that the protein consistently agglutinated mouse erythrocytes, suggesting that this protein possessed haemagglutinin properties. Interestingly, a direct reaction between the purified sub unit pili $49,6 \mathrm{kDa}$ protein and mice gastric epithelial cells in immunocytochemical staining was positive, coincided with those of haemagglutination assay. Furthermore, application of the isolated IgG on the pre-treated mice gastric epithelial cells with the purified sub unit pili 49,6 kDa proteins, repealed an inhibition of $H$. pylori cells to adhere the cells. This further suggested that the sub unit pili 49,6 kDa proteins had a specific adhesion molecules to bind the target gastric cells of mice. The inability of the bacteria to attach the gastric epithelial cells particularly when a high titer of IgG was added, confirming the sub unit pili 49,6 kDa protein was a functional protein that may associated with the pathogenesis of the bacteria.

Sumarno (2011) have found that combinations of protein adhesin sub-unit pili $37.8 \mathrm{kDa}$ V. cholerae with cholera toxin sub-unit B $V$. cholerae may be can as candidate vaccine of cholera. This results is opened to use as a consideration in developing $H$. pylori vaccine containing bacterial adhesion molecular component.

\section{Conclusion}

In vitro studies using western blotting analysis, hemagglutination test, adherence inhibition assays and immunocytochemical staining repealed that the $49,6 \mathrm{kDa}$ sub unit pili protein of $H$. pylori was immunogenic. The ability of this protein in agglutinating the mice erythrocytes, indicating it was haemagglutinin in nature. It was also confirmed that the protein possessed adhesion molecules that play a crucial role in the early phase of the pathogenesis $H$. pylori onto the epithelial cells of gastric. Further study is required to investigate the biological functions of this protein for protecting the infection by this microorganism in causing gastric ulcers.

\section{Acknownledgment}

The authors express many thanks for giving fund by our Ministry of Health Indonesia in the format of IPTEKDOK for the study. 


\section{Reference}

[1]. Clyne, M., B. Dolan, dan E. P. Reeves. 2007. Bacterial factors that mediate colonization of the stomach and virulence of Helicobacter pylori. FEMS Microbiol. Lett. 268: 135-143.

[2]. Cover, T. L., dan S. R. Blanke.2005. Helicobacter pylori VacA, a paradigm for toxin multifunctionality. Nat. Rev. Microbiol. 3:320-332 (Abs).

[3]. Groves, F. D., Perez-Perez, G., Zhang, L., Wei-cheng You, Lipsitz, S. R., Gail, M. H., Fraumeni Jr, J. F., danBlaser, M. J.2001. Serum Antibodies to Helicobacter pylori and the CagA Antigen Do Not Explain Differences in the Prevalence of Precancerous Gastric Lesions in Two Chinese Populations with Contrasting Gastric Cancer Rates. Cancer Epidemiol, Biomarkers \&prev, 11: 1091-1094.

[4]. Kaiser, G.E. 2011. The Prokaryotic Cell: Bacteria. The Community College of Baltimore Country, Catonsville Campus.

[5]. Laemmli U.K. 1970. Cleavage of Structural proteins during the assembly of the head of bacteriophage T4. Nature227(5259):680-5.

[6]. Leite, K. R. M., E. Darini, F. C. Canavez, C. M. de Carvalho, C. A. T. da Silveira Mitteldorf, and L. H. Camara-Lopez. 2005. Helicobacter pylori and cag A gene detected by polymerase chain reaction in gastric biopsies : correlations with histological findings, proliferation and apoptosis. Sao Paulo Med. J. 123 (3) : 113-118.

[7]. Nagayama, K Oguchi, T Arita, M Honda, T 1995,'Purification and Characterizations of a Cell-Associated Hemagglutinin of Vibrio parahaemoliticus, Infection and Immunity vol 63, pp 1987-1992.

[8]. Nunes, J. A. 1998. The play of environmental and genetic susceptibility and the differential ecologies of stomach cancer. Center for Social Studies and School of Economics University of Coimbra, Portugal.

[9]. Salyer, AA \& Whitt, DD 2002,' Bacterial Pathogenesis A Molecular Approach', ASM Press Washington DC, pp. 115-127.

[10]. Sumarno R.P, Uun Y, Winarsih S, Islam S and Sanarto S, 2012. Detection of molecule adhesion sub-unit pili 48 kDa Salmonella Typhi by immunochemistry method using sera patients suffering from typhoid fever. J. Basic. Appl. Sci. Res., 2(9)8527-8532.

[11]. Towbin, H., Stahelin, T. and Gordon, J. 1979. Electrophoretic transfer of protein from polyacrylamide gels to nitrocellulose sheets. Proc. Nat. Acad. Sci. USA 76:4350-4354.

[12]. Wiwik A, Fitri L.E, Raras T.Y.M, Siswanto B, and Sumarno R.P. 2012. Antibody Protein Hemagglutinin Subunit Pili with MW 49,8 kDa Shigella dysenteriae can inhibit Shigella dysenteriae adhesion on Mice Enterocyte. IOSR Journal of Pharmacy., 2 (5) .1320.

[13]. Sumarno, R.P., Susanto, A., Ismanoe, G. and Winarsih S. (2011). Combinations of Protein Sub-Unit PILI 37.8 kDa V. Cholerae with Cholera Toxin Sub-Unit B V. Cholerae Can Protect Come Out of the Solution in the Intestinal Mice. J. Pharm. Biomed. Sci., 1(8) $154-160$. 